\title{
ANALISIS PENGETAHUAN MASYARAKAT NON MUSLIM TERHADAP PERBANKAN SYARIAH DI KABUPATEN SERANG DAN KOTA SERANG
}

\author{
Khristina Sri Prihatin, Uun Fiana \\ khristinasriprihatin@unbaja.ac.id ${ }^{1}$, uunfiana@unbaja.ac.id ${ }^{2}$ \\ Universitas Banten Jaya \\ Serang, Indonesia
}

\begin{abstract}
This study aims to determine how the condition of knowledge / understanding of Non Muslim Communities of Islamic Banking in the District of Serang and the City of Serang.This research uses which are conducted by using questionnaires to 100 people (samples) Non Muslim who are spread in Serang Regency and Serang City. Of the 100 questionaires of 5 groups of Non Muslim Religions, Namely : Protestanstism, Katholicism, Hinduism, Buddhism And Confucianism.The results of this study indicate that the Non Muslim Community's knowledge of Islamic Banking is still very limited, most respondents only know the location of the spread of Islamic Banking in their area and only know the term revenue sharing without knowing how the system works in Islamic Banking. Knowledge of the characteristics of banking is still limited to knowing the term but does not yet know of any promotions carried out by Islamic Banking directly. Knowledge of non-Muslim communities has an effect between variables X1 and X2 together on $Y 1$ of $70.4 \%$ while the influence of variables X1 and X2 together on $Y 2$ is $80.6 \%$ and the value of $F$ arithmetic $>F$ table is $90,20>3.09$ and $47.92>3.09$ then the hypothesis of both effects is accepted.
\end{abstract}

Keywords: Knowledge of Non Muslim Communities, Islamic Banking, Profit Sharing System.

\section{PENDAHULUAN}

Di dalam dunia perbankan kita mengenal 2 (dua) sistem yang dilakukan dalam operasional bank, yaitu sistem konvensional dan sistem syariah. Kedua sistem perbankan ini menjadi pilihan bagi masyarakat dalam melakukan transaksi keuangan seperti menabung dan melakukan pinjaman serta kegiatan perbankan lain. Perbankan Syariah dan Perbankan Konvensional di Indonesia terus berkembang, meskipun kedua sistem ini mempunyai perbedaan terutama dalam masalah bunga bank, namun pada dasarnya kedua sistem ini mempunyai kesamaan dalam masalah pelayanan untuk menciptakan kepuasan pelanggan mereka masing-masing.

Provinsi Banten merupakan mayoritas masyarakatnya beragama muslim yakni sebesar $82 \%$ dari jumlah penduduk di Wilayah Banten, tetapi pengembangan produk syariah berjalan lambat dan belum berkembang 
sebagaimana halnya bank konvensional secara umum memiliki fungsi strategis sebagai lembaga intermedisi dan memberikan jasa dalam lalu lintas pembayaran namun karakteristik dari kedua bank tersebut dapat mempengaruhi calon nasabah dalam menentukan pilihan mereka terhadap kedua bank tersebut (Hamidi, hal 72 : 2015).

Tidak dapat dipungkiri bahwa muncul persepsi di kalangan masyarakat non muslim bahwa Perbankan Syariah hanya diperuntukkan pada masyarakat muslim dan tertutup untuk kalangan non muslim karena adanya fanatisme agama masih kental terlihat dalam masyarakat.

Dalam penelitian ini, penulis ingin menganalisis masyarakat non muslim terhadap bank syariah. Dengan berkembangnya bank syariah yang terus menerus menunjukan peningkatan sebagian besar nasabah non muslim tertarik untuk menyimpan dananya di Perbankan Syariah. Salah satu aspek yang menyebabkan tertariknya masyarakat non muslim terhadap bank syariah adalah sosialisasi tentang karakteristik perbankan syariah, serta untuk mengetahui tingkat pengetahuan masyarakat non muslim terhadap Perbankan Syariah dan Untuk menumbuhkan minat dan kepercayaan masyarakat non muslim terhadap perbankan syariah itu sendiri, baik itu mengenai pengertian, produk-produk dan promosi yang dilakukan oleh perbankan syariah.

Namun, yang terjadi di Kabupaten Serang dan Kota Serang Perbankan Syariah masih terdengar awam bagi masyarakat non muslim. Penulis mengidentifikasi masalah kurangnya faktor sosialisasi dan promosi yang seharusnya dilakukan oleh Perbankan Syariah kepada masyarakat Non Muslim di Kabupaten Serang dan Kota Serang. Sehingga berdampak pada kurangnya pengetahuan masyarakat non muslim mengenai Perbankan Syariah dan Produk- Produk yang terdapat di Perbankan Syariah Di Kabupaten Serang dan Kota Serang .

Oleh karena itu peneliti tertarik untuk melakukan penelitian "Analisis Pengetahuan Masyarakat Non Muslim Terhadap Perbankan Syariah di Kabupaten dan Kota Serang”

Secara etimologi pengetahuan berasal dari kata bahasa Inggris yaitu knowledge. Dalam Encyclopedia of Phisolophy dijelaskan bahwa definisi pengetahuan adalah kepercayaan yang benar). Ilmu atau pengetahuan dalam Islam mencangkup dua pengertian; 
pertama sampainya ilmu dari Allah ke dalam jiwa manusia, dan kedua, sampainya jiwa manusia terhadap objek ilmu melalui penelitian dan kajian. Secara terminologi akan dikemukakan beberapa definisi pengetahuan. Pengetahuan adalah hasil dari aktifitas mengetahui, yakni tersingkapnya suatu kenyataan ke dalam jiwa hingga tidak ada keraguan terhadapnya. Pengetahuan konsumen (customer knowledge) telah didefinisikan sebagai sejumah pengalaman dengan dan informasi tentang produk atau jasa tertentu yang dimiliki oleh seseorang. Dengan meningkatnya pengetahuan konsumen individu, hal ini memungkinkan bagi konsumen tersebut untuk berfikir tentang produk diantara sejumlah dimensi yang lebih besar dan mampu membedakan yang baik diantara merkmerk.

Dari beberapa pengertian pengetahuan di atas dapat disimpulkan bahwa pengetahuan adalah segala sesuatu yang diketahui dan diperoleh seseorang dari persentuhan panca indera terhadap objek tertentu. Menurut Mowen dan Minor (2014:106), pengetahuan konsumen dapat dibedakan menjadi 3 kategori yaitu, Pengetahuan Objektif, Pengetahuan Subjektif, dan
Informasi mengenai pengetahuan lainnya.

Menurut Peter dan Olson (2016:86) Pengetahuan Produk dibedakan menjadi diantaranya :

a. Pengetahuan tentang karakteristik atau atribut produk berupa warna, model, tahun, dan lain-lain. Ada dua macam atribut menggambarkan ciriciri suatu produk dan atribut-atribut abstrak yang menggambarkan karakteristik produk berdasarkan persepsi konsumen.

b. Pengetahuan tentang manfaat produk

c. Pengetahuan tentang kepuasan yang diberikan produk bagi konsumen.

Awal mula kegiatan Bank Syariah yang pertama sekali dilakukan adalah Pakistan dan Malaysia pada sekitar Tahun 1940-an. Kehadiran Bank yang berdasarkan syariah di Indonesia masih relatif baru, yaitu baru pada awal Tahun 1990-an, meskipun masyarakat Indonesia merupakan masyarakat muslim terbesar di dunia. Prakarsa untuk mendirikan Bank Syariah di Indonesia dilakukan oleh Majelis Ulama Indonesia (MUI) pada tanggal $18-20$ Agustus 1990. Namun, diskusi tentang Bank syariah sebagai basis ekonomi 
Islam sudah mulai dilakukan pada awal tahun 1980 (Kasmir, 2010: 35).

Seorang ahli ekonomi Islam, Sudarsono mengatakan, bank syariah adalah lembaga keuangan yang usaha pokoknya memberikan kredit atau pembiayaan dan jasa-jasa lainnya dalam lalu lintas pembayaran serta perederan uang yang pengoperasiannya, disesuaikan dengan prinsip-prinsip Syariah . (Sudarsono, 2014:29).

Menurut

Karnaen

Perwataatmadja (2013:67) Bank syariah merupakan bank yang menjalankan usaha perbankan dengan berdasar ataupun memperhatikan prinsip prinsip syariah yang tertuang di dalam Al-Qur'an dan Hadist. Dan menurut (Scahik) Perbankan syariah adalah suatu bentuk dari bank modern yang berlandaskan hukum-hukum agama Islam, yang dikembangkan pada abad pertengahan Islam dengan jalan menggunakan konsep bagi hasil dan bagi resiko sebagai sistem utama dan menghapuskan sistem keuangan yang dilandasi dengan anggapan kepastian keuntungan yang telah ditentukan sebelumnya (Scahik, 2015:45).

Perbankan syariah adalah segala sesuatu yang sering berkaitan bank syariah dan unit usaha syariah yang mencakup kelembagaan, kegiatan usaha hingga proses pelaksanaan kegiatan usahanya. (Menurut UU No. 21 Tahun 2008).

Menurut Mutasowifin (2013:36) dalam menjalankan aktivitasnya, Bank Syariah menganut prinsip-prinsip sebagai berikut: (1). Prinsip Keadilan. Prinsip ini dapat dilihat dari penerapan ganjaran atas dasar bagi hasil dan pengambilan margin keuntungan yang dipersetujui bersama antara Bank dengan Pelanggan; (2) Prinsip Hak yang sama. Bank Syariah meletakkan nasabah penyimpan dana, pelanggan pengguna dana, dan bank pada kedudukan yang sama dan sederajat. Produk-produk Bank Syariah telah sesuai dengan prinsip dan kaedah Muamalah Islam, antara lain tidak adanya unsur riba serta penerapan zakat harta. Dengan demikian, pelanggan akan merasakan ketentraman lahir maupun batin.

\section{Menurut Muhammad Syafi'i} Antonio (2010:77) pada dasarnya, produk yang ditawarkan oleh perbankan syariah dibagi atas tiga bagian besar, antara lain:

a. Produk Penyaluran Dana (Financing)

Dalam penyaluran dana pada nasabah, secara garis besar produk pembiayaan syariah terbagi kedalam 3 
(tiga) kategori yang dibedakan berdasarkan tujuan penggunaanya :

1) Pembiayaan dengan Prinsip Jual Beli (ba'i)

2) Pembiayaan dengan Prinsip Sewa (al Ijarah)

3) Pembiayaan dengan Prinsip Bagi Hasil (syirkah)

b. Produk Penghimpunan Dana (Funding) Penghimpunan dana di bank syariah dapat berbentuk giro, tabungan dan deposito. Prinsip operasional syariah yang diterapkan dalam penghimpunan dana masyarakat adalah:

1) Prinsip Wadi'ah

Wadi'ah prinsipnya adalah akad penitipan barang atau uang kepada koperasi, maka berkewajiban koperasi harus merawat barang atau uang titipan tersebut dengan baik, serta mengembalikan yang dititipkan saat penitip meminta kembali.

2) Prinsip Mudharabah

Penyimpanan atau bertindak sebagai pengelola. Rukun mudharabah terpenuhi sempurna (ada pemilik dana, ada usaha yang akan dibagi hasilkan, ada nisbah, ijab kabul).

c. Produk Jasa (Service)

Menurut Muhammad Syafi'i Antonio (2010:89), jasa perbankan penghubung antara pihak yang membutuhkan dana dengan pihak yang kelebihan dana, bank syariah dapat pula melakukan berbagai layanan jasa perbankan pada nasabah dengan mendapat imbalan berupa sewa atau keuntungan. Bank Syariah dapat melakukan berbagai pelayanan jasa perbankan kepada nasabah dengan mendapatkan imbalan berupa sewa atau keuntungan. jasa perbankan tersebut antara lain berupa valuta asing (al-sharf), sewa tempat simpanan (safe deposit box), dan jasa tata laksana administrasi dokumen (custodian).

Menurut Fandy Tjiptono (2015:219), pada hakikatnya promosi adalah suatu bentuk komunikasi pemasaran, yang di maksud komunikasi pemasaran adalah aktivitas pemasaran yang berusaha menyebarkan informasi, mempengaruhi atau membujuk, dan mengingatkan pasar sasaran atas produknya agar bersedia menerima, membeli, dan loyal pada produk yang ditawarkan perusahaan yang bersangkutan.

Menurut Fandy Tjiptono (2015:225) Promosi merupakan sarana yang paling ampuh untuk menarik dan mempertahankan nasabah. Salah satu 
tujuan promosi bank adalah menginformasikan segala jenis produk yang ditawarkan dan berusaha menarik calon nasabah yang baru. Kemudian promosi juga berfungsi mengingatkan nasabah terhadap produk, mempengaruhi nasabah untuk membeli dan akhirnya promosi akan meningkatkan citra bank dimata para nasabahnya.

Menurut Muhammad Quraish Shihab dalam bukunya Wawasan AlQuran (2013:98), dijelaskan mengenai non Muslim yakni orang selain dari orang Islam baik Yahudi, Nasrani maupun umat beragama yang lainnya. Dijelaskan juga mengenai non Muslim seperti Yahudi dan Nasrani, dua kelompok masyarakat yang minimal disepakati oleh seluruh ulama sebagai "ahl al-kitāb”. Selain istilah ahl al-Kitāb, al-Quran juga menggunakan istilah Utu al-Kitāb, Utū nasīban minal al-kitāb, al-Yahūd, al-Lazīna Hādu, Bani Isrā̄l, an Nashāra, dan istilah lainnya.

Al-Quran menggunakan kata alYahud, maka pasti ayat tersebut berupa kecaman atas sikap-sikap buruk mereka, dan jika menggunakan kata Nashara, maka ia belum tentu bersikap kecaman, sama halnya dengan al-Ladzīna hādu.

\section{METODE PENELITIAN}

\section{Waktu dan Tempat Penelitian}

Waktu penelitian dilaksanakan mulai Maret sampai dengan April 2020. Kuesioner disebarkan kepada Masyarakat Non Muslim yang berdomisili di Kabupaten Serang dan Kota Serang

\section{Metode Penelitian}

a. Populasi dan Sampel

Populasi dalam penelitian ini adalah seluruh Masyarakat Non Muslim Di wilayah Banten dengan jumlah populasi Masyarakat Non Muslim di Kabupaten Serang \& Kota Serang yaitu sebanyak 89.434 Jiwa.

Tabel 1 Data Penduduk Masyarakat Non Muslim

\begin{tabular}{cccccc}
\hline & & \multicolumn{2}{c}{ Kabupaten } & \multicolumn{2}{c}{ Kota } \\
No & Agama & $\begin{array}{c}\text { Jumlah \% } \\
\text { Penduduk }\end{array}$ & $\begin{array}{c}\text { Jumlah } \\
\text { Penduduk }\end{array}$ & $\begin{array}{c}\text { Jumlah } \\
\text { Prosentase } \\
\text { Penduduk }\end{array}$ & $\begin{array}{c}\text { Jumlah } \\
\text { Penduduk }\end{array}$ \\
\hline 1 & Katolik & $0,19 \%$ & 2.838 jiwa & $4.84 \%$ & $\begin{array}{c}34.486 \\
\text { jiwa }\end{array}$ \\
2 & Kristen & $0.60 \%$ & 8.961 jiwa & $3.77 \%$ & 26.862 jiwa \\
3 & Hindu & $0.02 \%$ & 299 jiwa & $0.23 \%$ & 1.639 jiwa \\
4 & Budha & $0.04 \%$ & 597 jiwa & $1.89 \%$ & 13.467 jiwa \\
5 & Konghucu & - & - & $0.04 \%$ & 285 jiwa \\
\multicolumn{2}{c}{ TOTAL } & $0.85 \%$ & 12.695 jiwa & $10.77 \%$ & 76.739 jiwa \\
\hline \multicolumn{5}{c}{ Populasi } \\
\hline
\end{tabular}

Sumber : Badan Pusat Statistik Provinsi Banten

Sampel pada penelitian ini adalah Masyarakat Non Muslim yang berdomisili khusus di Kabupaten Serang dan Kota Serang. di wilayah tersebut terdapat beberapa agama Non muslim seperti Kristen Protestan, Katolik, Budha, Hindu dan Konghucu. Penulis 
menggunakan Metode Slovin, Rumus

Slovin adalah sebuah rumus atau formula untuk menghitung jumlah sampel minimal apabila perilaku dari sebuah populasi tidak diketahui secara pasti. Berdasarkan hasil rumus tersebut penulis mengambil 100 sampel.

Tabel 2. Data Sebaran Responden

\begin{tabular}{cccc}
\hline No & Agama & $\begin{array}{c}\text { Rumus } \\
(\mathbf{N}=\text { Populasi/Jumlah } \\
\text { Populasi x 100 ) }\end{array}$ & $\begin{array}{c}\text { Jumlah } \\
\text { Kuesioner }\end{array}$ \\
\hline 1 & Katholik & $\mathrm{N}=\underline{\frac{37.324}{89.434} \times 100}$ & 41 \\
2 & Protestan & $\mathrm{N}=\underline{\frac{35.823}{89.434}} \times 100$ & 40 \\
3 & Budha & $\mathrm{N}=\underline{\frac{14.064}{89.434}} \times 100$ & 16 \\
4 & Hindu & $\mathrm{N}=\frac{1.938}{89.434} \times 100$ & 2 \\
5 & $\begin{array}{c}\text { Konghucu } \\
\text { Jumlah }\end{array}$ & $\mathrm{N}=\frac{285}{89.434} \times 100$ & 1 \\
\hline
\end{tabular}

Sumber : hasil penelitian 2020 (data diolah)

Karakteristik - karakteristik penelitian terdiri dari :

a. Karakteristik Berdasarkan Jenis kelamin

Dalam penelitian ini karakteristik jenis kelamin dibedakan antara jenis kelamin laki-laki dan perempuan. Adapun data dan persentase mengenai jenis kelamin responden non muslim di Kota Serang Dan Kabupaten Serang adalah sebagai berikut:

Tabel 3 Jumlah Responden Menurut Jenis Kelamin

\begin{tabular}{ccc}
\hline Jenis Kelamin & Nilai & Presentase \\
\hline Laki-laki & 39 Orang & $39 \%$ \\
Perempuan & 61 Orang & $61 \%$ \\
Jumlah & 100 Orang & $100 \%$ \\
\hline
\end{tabular}

Sumber : hasil penelitian 2020 (data diolah)
Berdasarkan keterangan pada tabel di atas dapat diketahui bahwa mayoritas responden adalah perempuan yaitu sebanyak 61 orang atau $61 \%$, sedangkan sisanya adalah laki-laki sebanyak 39 orang atau 39\%. Hal ini menunjukkan bahwa sampel yang diambil untuk penelitian ini adalah Perempuan lebih dominan dari pada Laki-Laki.

b. Karakteristik Berdasarkan Usia

Responden yang diambil sebagai sampel dalam penelitian ini dikelompokkan menjadi 4 kelompok, yaitu usia 17-25 tahun, 26-35 tahun, 36-45 tahun dan 46 tahun keatas. Adapun data dan persentase mengenai usia responden non muslim di Kota Serang Dan Kabupaten Serang adalah sebagai berikut:

Tabel 4 Jumlah Responden Menurut Usia

\begin{tabular}{ccc}
\hline Usia & Nilai & Presentase \\
\hline 17-25 tahun & 58 Orang & $58 \%$ \\
26-35 tahun & 26 Orang & $26 \%$ \\
36-45 tahun & 16 Orang & $16 \%$ \\
Jumlah & 100 Orang & $100 \%$ \\
\hline Sumber : hasil penelitian 2020 (data diolah)
\end{tabular}

Dari tabel di ketahui bahwa responden yang paling banyak adalah berusia 17-25 tahun yaitu sebanyak 58 orang atau 58\%. Usia 26-35 tahun sebanyak 26 orang atau 26\%. Dan yang paling sedikit adalah responden dengan usia 36-45 tahun yaitu sebanyak 16 orang atau $16 \%$. Hal ini menunjukan bahwa usia 
17-25 tahun adalah yang lebih dominan diambil sebagai sampel penelitian.

c. Karakteristik Berdasarkan Wilayah Responden yang diambil sebagai sampel dalam penelitian ini dikelompokkan menjadi 2 kelompok wilayah, yaitu Di Kota Serang dan Kabupaten Serang. Adapun data dan persentase mengenai wilayah responden non muslim adalah sebagai berikut:

Tabel 5 Jumlah Responden Menurut Wilayah

\begin{tabular}{|c|c|c|}
\hline Wilayah & Nilai & Presentase \\
\hline Kota Serang & 59 Orang & 59 \\
\hline $\begin{array}{l}\text { Kabupaten } \\
\text { Serang }\end{array}$ & 41 Orang & 41 \\
\hline Jumlah & 100 Orang & $100 \%$ \\
\hline
\end{tabular}

Sumber : hasil penelitian 2020 (data diolah)

Dari tabel diatas menunjukan bahwa kelompok wilayah di Kota Serang adalah yang lebih dominan diambil sebagai sampel penelitian dibandingkan dengan sampel di wilayah Kabupaten Serang.

\section{Pengolahan Data Hasil Temuan}

Tahap analisis data dalam penelitian ini yaitu dengan melakukan uji validitas dan reliabilitas dengan sampel 100 responden. Dari hasil analisis diketahui bahwa semua item pertanyaan yang digunakan adalah valid karena nilai rhitung $>\mathbf{r}$ tabel dan juga reliabel karena nilai Alpha Cronbach >0,60.

\section{Uji Validitas}

Uji validitas digunakan untuk mengukur sah atau valid tidaknya suatu kuesioner. Pengujian untuk menentukan signifikan atau tidak signifikan dengan membandingkan nilai $\boldsymbol{r}_{\text {hitung }}$ dengan $\boldsymbol{r}_{\text {tabel }}$. Jika $\mathrm{r}_{\text {hitung }}$ untuk tiap butir pertanyaan bernilai positif dan lebih besar dari $r_{\text {tabel }}$ (lihat corrected item-total correlation pada output progam SPSS 22), maka butir pertanyaan tersebut dikatakan valid, begitu pula sebaliknya. Untuk jumlah 100 responden dengan Rumus df $=(\mathrm{N}-2)$ maka $\mathrm{r}_{\text {tabel }}$ nya $\mathrm{df}=\left(\begin{array}{ll}100 & -2\end{array}\right)$ adalah 0,196.

\section{a. Variabel Pengetahuan $\left(\mathrm{X}_{1}\right)$}

Hasil uji validitas pada variabel Pengetahuan $\left(\mathrm{X}_{1}\right)$ adalah sebagai berikut:

Tabel 6. Rangkuman Validitas Instrumen Untuk Variabel Pengetahuan (X1)

\begin{tabular}{cccc}
\hline Pertanyaan & Rhitung & Rtabel & Validitas \\
\hline P1 & 0,658 & 0,196 & Valid \\
P2 & 0,836 & 0,196 & Valid \\
P3 & 0,759 & 0,196 & Valid \\
P4 & 0,779 & 0,196 & Valid \\
P5 & 0,776 & 0,196 & Valid \\
P6 & 0,287 & 0,196 & Valid \\
P7 & 0,665 & 0,196 & Valid \\
\hline
\end{tabular}

Sumber : hasil penelitian 2020 (Data diolah)

Berdasarkan tabel di atas, dapat diketahui bahwa nilai $r_{\text {hitung }}$ untuk keseluruhan butir pertanyaan variabel Pengetahuan (X1) lebih besar dari nilai $r_{\text {tabel }}$ sebesar 0,196 atau $r_{\text {hitung }}>r_{\text {tabel, }}$ hal ini berarti seluruh butir pertanyaan variabel pengetahuan dikatakan valid. 


\section{b. Variabel Promosi Perbankan ( $\left.\mathbf{X}_{2}\right)$}

Hasil uji validitas pada variabel Pengetahuan promosi perbankan $\left(\mathrm{X}_{2}\right)$ adalah sebagai berikut :

Tabel 7. Rangkuman Validitas Instrumen Untuk Variabel Promosi Perbankan (X2)

\begin{tabular}{cccc}
\hline Pertanyaan & Rhitung & Rtabel & Validitas \\
\hline P8 & 0,763 & 0,196 & Valid \\
P9 & 0,701 & 0,196 & Valid \\
P10 & 0,726 & 0,196 & Valid \\
P11 & 0,761 & 0,196 & Valid \\
P12 & 0,717 & 0,196 & Valid \\
\hline
\end{tabular}

Sumber : hasil penelitian 2020 (Data diolah)

Berdasarkan tabel di atas, dapat diketahui bahwa nilai $\mathrm{r}_{\text {hitung }}$ untuk keseluruhan butir pertanyaan variabel promosi perbankan (X1) lebih besar dari nilai $r_{\text {tabel }}$ sebesar 0,196 atau $r_{\text {hitung }}>r_{\text {tabel, }}$ hal ini berarti seluruh butir pertanyaan variabel promosi perbankan dikatakan valid.

\section{c. Variabel Karakteristik Perbankan $\left(\mathbf{Y}_{1}\right)$}

Hasil uji validitas pada variabel karakteristik perbankan $\left(\mathrm{Y}_{1}\right)$ adalah sebagai berikut :

Tabel 8. Rangkuman Validitas Instrumen Untuk Variabel Karakteristik Perbankan (Y1)

\begin{tabular}{cccc}
\hline Pertanyaan & Rhitung & Rtabel & Validitas \\
\hline P13 & 0,724 & 0,196 & Valid \\
P14 & 0,766 & 0,196 & Valid \\
P15 & 0,782 & 0,196 & Valid \\
P16 & 0,725 & 0,196 & Valid \\
P17 & 0,669 & 0,196 & Valid \\
\hline
\end{tabular}

Sumber : hasil penelitian 2020 (Data diolah)

Berdasarkan tabel di atas, dapat diketahui bahwa nilai rhitung untuk keseluruhan butir pertanyaan variabel karakteristik perbankan (Y1) lebih besar dari nilai $\mathrm{r}_{\text {tabel }}$ sebesar 0,196 atau $\mathrm{r}_{\text {hitung }}>\mathrm{r}_{\text {tabel, }}$, hal ini berarti seluruh butir pertanyaan variabel karakteristik perbankan dikatakan valid.

\section{d. Variabel Produk Perbankan $\left(\mathrm{Y}_{2}\right)$}

Hasil uji validitas pada variabel produk perbankan $\left(\mathrm{Y}_{2}\right)$ adalah sebagai berikut :

Tabel 9. Rangkuman Validitas Instrumen Untuk Variabel Produk Perbankan (Y2)

\begin{tabular}{cccc}
\hline $\begin{array}{c}\text { Pertanyaa } \\
\text { n }\end{array}$ & $\begin{array}{c}\text { Rhitun } \\
\text { g }\end{array}$ & $\begin{array}{c}\text { Rtabe } \\
\mathbf{l}\end{array}$ & $\begin{array}{c}\text { Validita } \\
\text { S }\end{array}$ \\
\hline P18 & 0,594 & 0,196 & Valid \\
P19 & 0,816 & 0,196 & Valid \\
P20 & 0,799 & 0,196 & Valid \\
P21 & 0,804 & 0,196 & Valid \\
P22 & 0,782 & 0,196 & Valid \\
\hline
\end{tabular}

Sumber : hasil penelitian 2020 (Data diolah)

Berdasarkan tabel di atas, dapat diketahui bahwa nilai $\mathrm{r}_{\text {hitung }}$ untuk keseluruhan butir pertanyaan variabel produk perbankan (Y2) lebih besar dari nilai $\mathrm{r}_{\text {tabel }}$ sebesar 0,196 atau $\mathrm{r}_{\text {hitung }}>\mathrm{r}_{\text {tabel, }}$ hal ini berarti seluruh butir pertanyaan variabel produk perbankan dikatakan valid.

\section{Uji Reliabitas}

Menurut Supriyatno (2014:64) untuk menghitung reliabilitas dilakukan dengan menggukan koefesien Croanbach Alpha. Instrument untuk mengukur masing-masing variabel dikatakan reliabel jika memiliki Croanbach Alpha > 0,6 maka butir pertanyaan atas variabel yang diteliti adalah reliabel.

Dimana berikut adalah hasilnya : 
a. Uji Realibitas Variable Pengetahuan

\section{Tabel 10. Reliability Statistics}

\begin{tabular}{cc}
\hline $\begin{array}{c}\text { Cronbach's } \\
\text { Alpha }\end{array}$ & N of Items \\
\hline .809 & 7 \\
\hline
\end{tabular}

Sumber : hasil penelitian 2020 (Data diolah menggunakan SPSS 22)

b. Uji Realibitas Variable Promosi Perbankan

\section{Tabel 11. Reliability Statistics}

\begin{tabular}{lc}
\hline Cronbach's Alpha & N of Items \\
\hline .784 & 5 \\
\hline \multicolumn{2}{c}{ Sumber : hasil penelitian 2020 (Data diolah) } \\
c. $\quad$ Uji Realibitas Karakteristik Produk \\
Perbankan
\end{tabular}

Tabel 12. Reliability Statistics

\begin{tabular}{cc}
\hline $\begin{array}{c}\text { Cronbach's } \\
\text { Alpha }\end{array}$ & N of Items \\
\hline .783 & 5
\end{tabular}

Sumber : hasil penelitian 2020 (Data diolah)

d. Uji realibitas variable produk perbankan

\section{Tabel 13. Reliability Statistics}

Cronbach's

\begin{tabular}{cc} 
Alpha & N of Items \\
\hline Sumber : hasil penelitian & 5 \\
menggunakan SPSS 22) &
\end{tabular}

Tabel 14. Rangkuman Uji Reliabel Alpha Cronbach

\begin{tabular}{cccc}
\hline Variabel & Ralpha & $\begin{array}{c}\text { Alpha } \\
\text { Cronbach }\end{array}$ & Ket \\
\hline Pengetahuan $\left(\mathrm{X}_{1}\right)$ & 0,809 & 0,60 & Reliabel \\
Promosi Perbankan $\left(\mathrm{X}_{2}\right)$ & 0,784 & 0,60 & Reliabel \\
Karakteristik Perbankan $\left(\mathrm{Y}_{1}\right)$ & 0,783 & 0,60 & Reliabel \\
Produk Perbankan $\left(\mathrm{Y}_{2}\right)$ & 0,818 & 0,60 & Reliabel
\end{tabular}

Sumber : hasil penelitian 2020 (Data diolah menggunakan SPSS 22)

\section{Uji Asumsi Klasik}

Uji Normalitas

Pengujian asumsi ini bertujuan untuk menguji apakah dalam model regresi variabel terikat dan variabel bebas keduanya mempunyai distribusi normal ataukah tidak.

One-Sample Kolmogorov-Smirnov Test

\begin{tabular}{llr}
\hline \multicolumn{2}{c}{ One-Sample Kolmogorov-Smirnov Test } \\
& & $\begin{array}{c}\text { Unstandardized } \\
\text { Residual }\end{array}$ \\
& & 100 \\
\hline Normal Parameters & & Mean \\
& Std. Deviation & 2.74551332 \\
Most Extreme & Absolute & .0000000 \\
Differences & Positive & .056 \\
& Negative & -.061 \\
Test Statistic & & .061 \\
Asymp. Sig. (2-tailed) & & $.200^{\mathrm{c}, \mathrm{d}}$ \\
\hline
\end{tabular}
a. Test distribution is Normal.
b. Calculated from data.
c. Lilliefors Significance Correction.
d. This is a lower bound of the true significance. Sumber : hasil penelitian 2020 (Data diolah)

Berdasarkan tabel diatas, diketahui bahwa nilai statistik uji Kolmogorov-Smirnov $Z$ (Test Statistic) sebesar 0,61 dan nilai Asyimp. Sig sebesar 0,200 >0,05, dapat disimpulkan bahwa metode ini menunjukkan kearah hasil yang baik dan data yang telah di perhitungkan dapat dikatakan data residual normal.

\section{ANALISA DATA}

Korelasi Berganda (multiple correlation) merupakan angka yang menunjukkan arah dan kuatnya hubungan antara dua variabel independen secara 
bersama-sama atau lebih dengan satu variabel Independen (Sugiyono, 2017:83)

Berikut merupakan perhitungan hasil analisis korelasi berganda dengan menggunakan Aplikasi SPSS :

a. Hasil analisis korelasi berganda variabel Pengetahuan (X1) Dan variabel Promosi Perbankan (X2) Terhadap Variabel Karakteristik Perbankan (Y1)

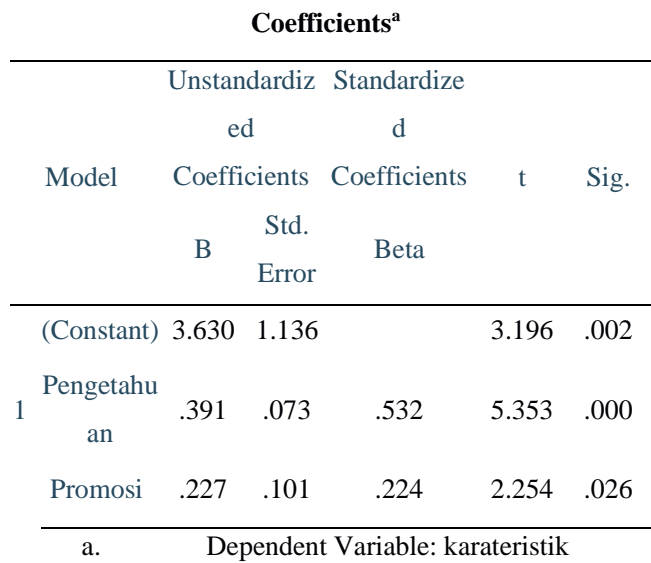

b. Hasil analisis korelasi berganda variabel Pengetahuan (X1) Dan variabel Promosi Perbankan (X2) Terhadap Variabel Promosi Perbankan (Y2)

\begin{tabular}{cccccc}
\multicolumn{8}{c}{ Coefficients $^{\mathbf{a}}$} \\
\hline \multirow{2}{*}{ Model } & Unstandardized & Standardized & & \\
& Coefficients & Coefficients & $\mathrm{T}$ & Sig. \\
& $\mathrm{B}$ & Std. Error & Beta & & \\
\hline (Constant) & .746 & 1.001 & & .746 & .000 \\
pengetahuan & .471 & .064 & .607 & 7.331 & .000 \\
promosi & .276 & .089 & .258 & 3.109 & .002 \\
& a. Dependent Variable: produk & &
\end{tabular}

Table 15. Rangkuman hasil analisis korelasi berganda dalam pengambilan keputusan korelasi :

\begin{tabular}{lll} 
Variabel & $\begin{array}{c}\text { Nilai } \\
\text { Sig. F }\end{array}$ & Keterangan \\
\hline Variabel & & \\
Pengetahuan & & \\
$\left(\mathrm{X}_{1}\right) \quad$ Dan & & \\
Variabel & & \\
Promosi & 0,02 & Berkorelasi \\
Perbankan & & \\
$\left(\mathrm{X}_{2}\right)$ Terhadap & & \\
Variabel & & \\
Karakteristik & & \\
Perbankan (Y1) & & \\
Variabel & & \\
Pengetahuan & & \\
(X1) & \\
Variabel & & \\
Promosi & & \\
Perbankan & 0.00 & Berkorelasi \\
(X)Terhadap & \\
Variabel & \\
Promosi & \\
Perbankan (Y2) & \\
\hline Sumber : hasil penelitian 2020 (data di olah)
\end{tabular}

Table 4.2 Rangkuman hasil analisis korelasi berganda menentukan derajat hubungan:

\begin{tabular}{|c|c|c|}
\hline Variabel & $\begin{array}{c}\text { Nilai } \\
\text { Pearson }\end{array}$ & Keterangan \\
\hline Variabel & \multirow{10}{*}{0,532} & \multirow{10}{*}{$\begin{array}{l}\text { Korelasi } \\
\text { Sedang }\end{array}$} \\
\hline Pengetahuan & & \\
\hline$\left(\mathrm{X}_{1}\right) \quad$ Dan & & \\
\hline Variabel & & \\
\hline Promosi & & \\
\hline Perbankan & & \\
\hline$\left(\mathrm{X}_{2}\right)$ Terhadap & & \\
\hline Variabel & & \\
\hline Karakteristik & & \\
\hline Perbankan (Y1) & & \\
\hline Variabel & \multirow{10}{*}{0,607} & \multirow{10}{*}{ Korelasi Kuat } \\
\hline Pengetahuan & & \\
\hline$\left(\mathrm{X}_{1}\right) \quad$ Dan & & \\
\hline Variabel & & \\
\hline Promosi & & \\
\hline Perbankan & & \\
\hline$\left(\mathrm{X}_{2}\right)$ Terhadap & & \\
\hline Variabel & & \\
\hline Promosi & & \\
\hline Perbankan (Y2) & & \\
\hline
\end{tabular}




\section{Pembahasan}

Setelah melakukan beberapa pengujian secara umum hasil analisis penelitian ini menunjukkan kondisi penilaian responden terhadap variabelvariabel penelitian. Hal ini dapat dilihat dari banyaknya tanggapan persetujuan dari responden terhadap kondisi dari masing-masing variabel penelitian.

Hasil analisis regresi menghasilkan urutan besarnya variabel-variabel independen yang berbeda. Ini terlihat dari besarnya koefisien reliabel dari yang terbesar sampai yang terkecil berturutturut Produk Perbankan sebesar $(0,818)$, Pengetahuan sebesar $(0,809)$, Promosi Perbankan sebesar $(0,784)$ dan Karakteristik Perbankan sebesar $(0,783)$. Semua variabel berpengaruh terhadap Pengetahuan masyarakat non muslim terhadap Perbankan Syariah di Kabupaten Serang dan Kota Serang dengan dilakukan uji secara parsial.

Variabel yang paling dominan adalah variabel produk perbankan. Ini menandakan bahwa diantara ke empat variabel independen yang diuji pengaruh, variabel inilah yang memberikan kontribusi paling besar yaitu sebesar 0,818 dalam pengetahuan mengenai istilah-istilah yang ada dalam produkproduk Perbankan Syariah.
Sedangkan variabel Pengetahuan menempati urutan berikutnya sebesar 0,809 dalam hal ini menunjukan bahwa pengetahuan masyarakat non muslim terhadap Perbankan Syariah juga sudah mulai banyak baik mengenai lokasi Perbankan Syariah yang tersebar di wilayah mereka dan juga beberapa istilah yang sudah banyak di ketahui oleh masyarakat non muslim dalam Perbankan Syariah seperti istilah Bagi Hasil.

1. Hasil dari analisis korelasi berganda X1 Dan X2 Terhadap Y1 di dapat bahwa : Variabel X1 Dan X2 terhadap Y1 Nilai Sig. F sebesar 0,02 maka dapat dikatakan berkorelasi, dan nilai earson yang di dapat sebesar 0,532 maka dalam derajat hubungan nya termasuk kedalam korelasi sedang, sedangkan untuk nilai $\mathrm{F}$ hitung > F table yaitu sebesar 47,92 > 3,09 maka Hipotesis Diterima.

2. Hasil dari analisis korelasi berganda X1 Dan X2 Terhadap Y2 di dapat bahwa : Variabel X1 Dan X2 Terhadap Y2 Nilai Sig. F Sebesar 0,00 maka dapat dikatakan berkorelasi, dan nilai earson yang di dapat sebesar 0,607 maka dalam derajat hubungan nya termasuk kedalam korelasi kuat, sedangkan nilai $\mathrm{F}$ hitung $>\mathrm{F}$ table yaitu sebesar 
90,20> 3,09 maka Hipotesis

Diterima.

3. Analisis pengetahuan masyarakat non muslim terhadap perbankan syariah. Pengetahuan Masyarakat non muslim terhadap bank syariah menunjukkan bahwa sebagian besar responden mengetahui tentang lokasi perbankan syariah yang ada di wilayah mereka, mengetahui istilah sistem bagi hasil dan sebagian masyarakat non muslim sudah mengetahui bahwa perbankan syariah juga terbuka bagi masyarakat non muslim dengan kata lain bukan hanya diperuntukan bagi masyarakat islam saja. Namun pengetahuan masyarakat non muslim masih terbatas mengenai arti dari istilah-istilah serta produk yang ada di dalam perbankan syariah seperti mudharabah, musyarakah, murabahah dan ijarah. Hasil ini memberikan bukti bahwa selama ini bank syariah belum cukup melakukan promosi untuk memperkenalkan produk-produk bank syariah, terutama promosi melalui media elektronik maupun media cetak. Mayoritas masyarakat non muslim mengetahui tentang Perbankan Syariah masih berdasarkan informasi dari bangku perkuliahan, teman atau keluarga mereka.

\section{KESIMPULAN DAN SARAN}

\section{Kesimpulan}

Berdasarkan hasil analisis dari hasil penelitian mengenai pengetahuan masyarakat non muslim terhadap Perbankan Syariah di Kabupaten Serang dan Kota Serang, maka dapat disimpulkan:

Pengetahuan masyarakat non muslim terhadap perbankan syariah masih sangat terbatas, sebagian besar responden hanya mengetahui lokasi penyebaran perbankan syariah di wilayah mereka serta hanya mengetahui istilah bagi hasil tanpa mengetahui bagaimana sistem yang berjalan di dalam Perbanakan Syariah.

Pengetahuan masyarakat tentang karakteristik perbankan masih sebatas mengenal istilah namun belum mengetahui arti lebih jauh. Serta tidak mengetahui adanya promosi yang dilakukakan oleh perbankan syariah secara langsung. Sedangkan istilah-istilah perbankan syariah seperti musyarakah, murabahah dan ijarah sudah diketahui namun belum dimengerti oleh masyarakat..

Pengetahuan masyarakat non muslim memliliki pengaruh antara variable $\mathrm{X} 1$ 
Dan X2 secara bersama-sama terhadap Y1 sebesar 70,4\% sedangkan pengaruh variable X1 Dan X2 secara bersama-sama terhadap Y2 Sebesar $80,6 \%$ serta nilai F hitung $>$ F table yaitu sebesar 90,20 > 3,09 dan 47,92 > 3,09 maka Hipotesis kedua pengaruh tersebut Diterima.

\section{Saran}

1. Bagi Perbankan Syariah

Untuk lebih memperkenalkan Bank Syariah kepada masyarakat sebaiknya lebih gencar lagi melakukan promosi melalui media cetak maupun elektronik serta menciptakan strategi promosi baru yang lebih menarik atau yang tidak diberikan oleh pesaing lainnya.

2. Bagi Penelitian

Penelitian ini dapat dijadikan referensi untuk penelitian selanjutnya, yaitu variabel apa saja yang menjadi daya tarik masyarakat non muslim untuk mengetahui dan mengeal lebih jauh mengenai perbankan syariah. Penelitian serupa sebaiknya dilakukan dengan menambah objek penelitian pada salah satu bank syariah, sehingga penelitian tersebut dapat mewakili kondisi bisnis perbankan syariah pada suatu wilayah tertentu serta didapatkan suatu prioritas perbaikan dari kualitas jasa perbankan syariah.

3. Bagi Subjek Penelitian
Dalam hal ini yaitu masyarakat non muslim agar dapat lebih terbuka untuk mengetahui hal-hal yang berkaitan dengan Perbankan Syariah sehingga dapat membuka pola pikir masyarakat non muslim bahwa Perbankan Syariah memang tidak hanya di prioritaskan untuk masyarakat muslim saja tetapi juga untuk masyarakat umum lainnya.

\section{DAFTAR PUSTAKA}

Annisa, Fayzah. (2018). Faktor-faktor Yang Mempengaruhi Masyarakat Terhadap Perbankan Syariah. Yogyakarta : CV Andi.

Anonim. (2014). Undang-undang No. 10 Tahun 1998 tentang Perubahan Undang-undang No. 07 Tahun 1992. Jakarta: Sinar Grafika

Anonim. (2014). Undang-undang No. 07 Tahun 1992 tentang Perbankan. Jakarta: Sinar Grafika.

Antonio, Karnaen Perwataatmadja. (2013). Apa dan Bagaimana Bank Islam. Yogyakarta: Dana Bhakti Wakaf.

Antonio, Muhammad Syafi'i. (2011). Bank Syariah Dari Teori Ke Praktik. Jakarta: Gema Insani Press.

Kasmir. (2010). Bank dan Lembaga Keuangan Lainnya. Jakarta: Grafindo Persada.

Mowen, Jhon C. Michael Minor. (2014). Consumer Behavior 6 ed. New jersey: Prentice-Hall. Inc

S Setiawan. (2016). Perbankan Syariah, Yogyakarta: TrustMedia.

Scahik, D. (2013). Islamic Banking The Arab Bank Review. Hal 45 
Shihab, Muhammad Quraish. (2015). Wawasan Alquran. Jakarta: PT Mizan Pustaka.

Sudarsono, Heri. (2014). Bank dan Lembaga Keuangan Syariah. Deskripsi dan Ilustri.Yogyakarta:Ekosoria,Hal 29

Sugiyono.(2017).Metode Penelitian Kuantitatif Kualitatif dan $R \& D$. Bandung: Alfabeta.

Sujarweni.(2014).Metode dan Rumus Slovin. Hal :66

Tjiptono, Fandy. (2016). Strategi Mengukur Kepuasan dan Loyalitas Pelanggan. Yogyakarta: Budi Utama.

Tjiptono, Fandy. (2015). Service, Quality dan Satisfaction. Yogyakarta: CV Andi.

Peter, Paul dan Jerry C.Olson. (2016). Consumer Behavior Perilaku Konsumen dan Strategi Pemasaran Edisi Keempat, Jakarta: Penerbit Erlangga.
Umar, Husen.(2013). Riset Pemasaran dan Perilaku Konsumen. Jakarta: Gramedia Pustaka Utama.

Badan Pusat Statistik Provinsi Banten. (12 Januari 2020).

Duwi. (2017) Perhitungan uji validitas Dan Reliabilitas pada kuesioner. Tersedia:

http://duwiconsultan.wordpress.co $\mathrm{m} / 2017 /$ uji-validitaskuisioner.html. (02 April 2020).

Ismiyanti, Nina. (2015) Persepsi nasabah non muslim terhadap Bank Syariah. Tersedia:

https://id.scribd.com/doc/24636628 4/persepsi-nasabah-non-muslimterhadap-bank-syariah. (07 Januari 2020).

Sintang. (2018) Mengenal produk-produk Bank Syariah. Tersedia : http://uchinfamiliar.blogspot.com/2 010/10/produk-produk-banksyariah.html. (07 Januari 2020). 
